\title{
Intellectual Property in Personalised Medicine
}

\section{Jamie R Love ${ }^{1}$ and Edward D Blair ${ }^{2 *}$}

${ }^{1}$ Synapses Ltd, Millbrae Cottage, Mill of Fyall, Alyth, Perthshire, PH11 8LB, UK

${ }^{2}$ Integrated Medicines Ltd, Topfield Croft, Ermine Street, Caxton, Cambridgeshire, CB23 3PQ, UK

\begin{abstract}
The economic value of intellectual property associated with prognostic and predictive tests is being increasingly recognised, such that some tests with established impact on healthcare pathways can command a premium reimbursement price from payers. Here we examine a number of seminal cases where the economic value of key tests has been hugely affected by the rulings and counter-rulings of the American justice system, with further impact on European and other markets.
\end{abstract}

Keywords: Precision; Predictive Medicine; Companion; Prognostic; Predictive test; District; Supreme Court of United States; Patentable Inventions

\section{Introduction}

The personalisation of medicines, beginning with selection of antimicrobial therapies in the late $20^{\text {th }}$ century and extending to cancer therapies as we moved into the $21^{\text {st }}$ century [1], has fostered a closer linkage between the pharmaceutical/biotechnology industries and the medical diagnostics/devices industry. The development of companion and complementary diagnostics $(\mathrm{CDx}, \mathrm{cDx})$, i.e., tests that predict if a patient will respond to a particular medicine (FDA), suggests that the utility of biomarkers incorporated in such tests extends from their traditional base of diagnosing disease to something equally evident in the response to treatment. While the economic value of such $\mathrm{CDx} / \mathrm{cDx}$ tests [2] remains largely unrewarded -the exceptions being prognostic tests for recurrence of certain cancers [3], the intellectual property value of such biomarkers and tests has been clearly recognised in the United States and elsewhere.

The United States is the world's largest market for products and services in biotechnology and medicine, so its laws and court decisions will continue to direct and limit these markets. This is particularly so with regards to patents.

United States Code 35 (35USC) governs all patent laws in the US. There are currently 37 Chapters in 35USC and our attention is drawn to Chapter 10 -"Patentability of Inventions" where we find section 101 (\$101) which says "whoever invents or discovers any new and useful process, machine, manufacture, or composition of matter, or any new and useful improvement thereof, may obtain a patent therefor, subject to the conditions and requirements of this title."

That doesn't sound very ominous. It doesn't sound like a patentkiller. Surely it can't harm an industry? And, indeed, it can't. Section 101 of the 35USC is the legislation cited by lawyers, judges etc. to support the court decisions that are promulgated as case laws.

Case laws are legal principles derived from judicial decisions. They are not statutes (laws) and it's important to understand the differences. Case laws are created by the judicial branch of the US government -by judges who are appointed (by elected officials). Up to nine judges may take part in a single trial. Statutes, by comparison, are created by the legislative branch of the US government which is composed of 535 elected members that constitute Congress (House of Representatives and the Senate). Congress is responsible to its citizens. The Supreme Court is not.
Case law is not "real law" - it's an interpretation of the law, usually under specific circumstances. However, case law is powerful because it establishes precedent which is binding on or persuasive for courts deciding subsequent cases with similar issues or facts. Higher court decisions are binding on lower courts. The ninety-four District Courts (serving bits and pieces of all fifty states plus US territories) have the lowest rank and the (sole) Supreme Court has the highest. Between them are the Court of Appeals, which "re-do" District Court cases if (and only "if") the law was not applied correctly. A special Court of Appeals for the Federal Circuit has nationwide jurisdiction to hear appeals involving US patents, customs and international trade laws.

The US Supreme Court, as the highest court in the land, has the final say. It is usually an appellate court but there is no is right of appeal to the Supreme Court. The Supreme Court chooses which cases to hear, by granting writs of certiorari. A writ of certiorari is issued by a superior court, directing an inferior court, tribunal, or other public authority to send the record of a proceeding for review. The Supreme Court grants a petition for certiorari only for "compelling reasons".

Most Supreme Court and the Federal Circuit cases are heard by more than one judge so decisions may be unanimous or not, but the majority rules.

\section{Patents and Patentability}

Section 101 is the first hurdle an application must clear on its way to becoming a patent and is usually the easiest. (Most patent applicants are rejected due to $\$ 102$ "novelty" or $\$ 103$ "non-obvious subject matter".) Patentability is not a static concept and Supreme Court decisions can change it. For example, the Supreme Court's decision in Diamond v. Chakrabarty (1980) [4] held "A live, human-made micro-organism is patentable subject matter under $\$ 101$. Respondent’s micro-organism constitutes a "manufacture" or "composition of matter" within that statute". Whether or not an invention embraced living matter is

*Corresponding author: Blair ED, Integrated Medicines Ltd, Topfield Croft, Ermine Street, Caxton, Cambridgeshire, CB23 3PQ, UK, Tel: +44 1954 718122; E-mail: eddie.blair@integratedmedicines.co.uk

Received August 20, 2016; Accepted September 02, 2016; Published September 10,2016

Citation: Love JR, Blair ED (2016) Intellectual Property in Personalised Medicine. Intel Prop Rights. 4: 164. doi: 10.4172/2375-4516.1000164

Copyright: ( 2016 Love JR, et al. This is an open-access article distributed under the terms of the Creative Commons Attribution License, which permits unrestricted use, distribution, and reproduction in any medium, provided the original author and source are credited. 
irrelevant to patentability. Instead, the test for patentability is whether or not the invention is the result of human intervention. The Court continued, "This is not to suggest that $\$ 101$ have no limits or that it embraces every discovery. The laws of nature, physical phenomena, and abstract ideas have been held not patentable."

These new guidelines later supported decisions in lower courts and boards.

The diagnostic tools and techniques that underpin the Intellectual Property in personalised medicine have been wrestling with the USPTO over $\$ 101$ for about a decade and, unlike Diamond v. Chakrabarty, the Supreme Court has not been helpful.

\section{Mayo v. Prometheus - from Machine Tests to Laws of Nature}

US patent \#6,355,623 [5] was granted to inventors Seidman and Théorêt on 12 March 2002. The claims protect their method of optimizing treatment for immune-mediated gastrointestinal disorders, by adjusting the dose of the medication (6-thioguanine) administered in order to maintain its concentration within a specific range (of 230 to 400 pmol per $8 \times 10^{8}$ red blood cells). On 20 January 2004 US patent $6,680,302$ [6] (a continuation of the original application) was granted, extending protection to maintain a specific metabolite (6-methylmercaptopurine) below a specific value $\left(7000\right.$ pmol per $8 \times 10^{8}$ red blood cells).

The inventors assigned both patents to their employer, HospitalSainte-Justine (Montreal, CA), who licensed them exclusively to Prometheus Laboratories - a specialty pharmaceutical and diagnostics company. The test was popular and amongst its users were Mayo Collaborative Services and Mayo Clinic Rochester (Mayo). In 2004 Mayo announced that it would market and sell its own, similar but different, diagnostic test.

Prometheus sued Mayo for infringement and a District Court judge agreed with Prometheus but concluded that the processes were unpatentable, because they simply described a natural law - how the human body metabolizes a drug.

A Federal Circuit reversed this decision ruling that the processes were patent eligible under the Circuit's "machine or transformation test."

The "machine or transformation test" says a claim to a process qualifies for patent consideration if it (1) is implemented by a particular machine in a non-conventional and non-trivial manner or (2) transforms an article from one state to another.

Prometheus' test uses a particular machine -a quantitative HPLC (High Pressure Liquid Chromatography) machine - to identify and measure the amount of the metabolites on red blood cells.

The Supreme Court put the "machine or transformation test" in its place with its decision in Bilski v. Kappos [7]. They ruled that" The machine-or-transformation test is not the sole test for patent eligibility under $\$ 101$. The Court's precedents establish that although that test may be a useful and important clue or investigative tool, it is not the sole test for deciding whether an invention is a patent-eligible "process" under $\$ 101$."

With that as background, Mayo appealed to the Supreme Court. The Court (unsurprisingly) orders the decision of the Federal Circuit to be "vacated" and order the lower court to retrial in light of their Bilski ruling. However, the Federal Circuit came to the same verdict as before
Mayo appealed to the Supreme Court and the Court agreed to hear the case.The Supreme Court reversed the decision of the Federal Circuit concluding that Prometheus was trying to claim a law of nature -a metabolic pathway [8]. Judge Breyer summarised the unanimous decision this way.

"If a law of nature is not patentable, then neither is a process reciting a law of nature, unless that process has additional features that provide practical assurance that the process is more than a drafting effort designed to monopolize the law of nature itself. A patent, for example, could not simply recite a law of nature and then add the instruction "apply the law." Einstein, we assume, could not have patented his famous law by claiming a process consisting of simply telling linear accelerator operators to refer to the law to determine how much energy an amount of mass has produced (or vice versa)."

\section{Ariosa v. Sequenom - Old Methods and New Ideas}

US patent \#6,258,540 [9] is built upon the surprising confirmation (rumoured for years and supported by irreproducible results) that cellfree fetal DNA (cffDNA) circulates in the mother's plasma. Claim 1 reads.

"A method for detecting a paternally inherited nucleic acid of fetal origin performed on a maternal serum or plasma sample from a pregnant female, which method comprises: amplifying a paternally inherited nucleic acid from the serum or plasma sample and detecting the presence of a paternally inherited nucleic acid of fetal origin in the sample." Isis Innovation Limited, the assignee for this patent, licensed it exclusive to Sequenom [10] but several companies started marketing the test at a lower price. Sequenom sent each of them letters threatening to file suits for infringement. Ariosa was one of them. The district court held the patent invalid; Sequenom was simply using an obvious method to detect a natural phenomenon and to claim this phenomenon for protection by patent would block development of other technologies that might arise using paternally inherited cffDNA.

Sequenom appealed to the Federal Circuit but the panel of three judges affirmed the district court's ruling, saying that test that the Supreme Court developed in Mayo identified the claims as a natural law or phenomenon. The Federal Circuit [11] said, "(the) method begins and ends with a natural phenomenon" (i.e., cffDNA) and did not "transform phenomenon into a patent-eligible application" of the phenomenon. Researchers already knew how to (1) fractionate blood; (2) amplify DNA; and (3) detect the amplified products. Therefore, the subject matter was patent-ineligible as a matter of law.

However, the ruling was not unanimous. Senior Judge Linn concurred but did not join in the decision separately, saying that he was "bound by the sweeping language of the test set out in Mayo." $\mathrm{He}$ also considered the Supreme Court's Mayo decision incorrect. "This case represents the consequence -perhaps unintended -of that broad language in excluding a meritorious invention from the patent protection it deserves and should have been entitled to retain."

Given this opinion, Sequenom sought a rehearing en banc (heard before all the judges of a court, the entire bench, rather than by a panel selected from them.) The diagnostics community was very disappointed when the rehearing was denied. The logic of the denial is that, in light of Mayo, Sequenom’s application could not pass $\$ 101$. It’s only “inventive step" was to apply known methods in the Prior Art, practiced by many and obvious to those in the field. The rehearing was not intended to put Mayo "on trail". Mayo stands (So Sequenom falls!). 
Judges Lourie and Moore opined that the Mayo ruling means that "nothing in the physical universe would be patent-eligible" and it's "unsound to have a rule that takes inventions of this nature out of the realm of patent-eligibility on grounds that they only claim a natural phenomenon plus conventional steps."

Judge Dyk wrote that Mayo "concludes that inventive concept cannot come from discovering something new in nature" and this was undesirable. He continued "Mayo did not fully take into account the fact that an inventive concept can come not just from creative, unconventional application of a natural law, but also from the creativity and novelty of the discovery of the law itself. This is especially true in the life sciences... I worry that method claims that apply newly discovered natural laws and phenomena in somewhat conventional ways are screened out by the Mayo test."

He acknowledged that nature and natural phenomena should be excluded (patent trolls would abuse it) and made a novel suggestion - if the claim is "sufficiently limited to a specific application of the new law of nature discovered by the patent applicant and [actually] reduced to practice, I think that the novelty of the discovery should be enough to supply the necessary inventive concept."

If Dyk had his way, patent examiners would have to determine if the claim over a new discovery was "sufficiently limited". Those who examine applications at the USPTO follow a strict "rule book" (the MPEP) to cover anticipation and obviousness but "sufficiently limited" is harder to argue (fairly) - especially due to the fact that this application would be based on very new developments in the field. There are very few experts in a new field and they rarely work for the USPTO. If the second line of Claim 1 had read "amplifying a paternally inherited nucleic acid flanking the "Iowna gene" (a fictitious gene) from the serum or plasma sample" the Examiner might allow it -under Dyk's method. But, of course, the applicant will try to protect his/her territory and those territories likely in the future. This is manageable (it is done today with obviousness in light of Prior Art) but could be difficult to practice. But that's the genius of the second part of Judge Dyk's solution.

Reduction to practice is an old friend at the USPTO -especially when deciding on an interference -a proceeding now on the scrap pile because the US joined the rest of the civilised patent offices by killing the "first to invent" (not file) system to allocate priorities in patent applications.

Judge Dyk nailed it when he added, "My proposed approach would require that the claimed application be both narrow in scope and actually reduced to practice, not merely "constructively" reduced to practice by filing of a patent application replete with prophetic examples [S]o long as a claim is narrowly tailored to what the patent applicant has actually invented and reduced to practice, there is limited risk of undue pre-emption of the underlying idea."

\section{Genius. Pure genius! (Dyk's a keeper) Now What?}

It's risky trusting that the Supreme Court will "man up" and says "Oops! Got that wrong". The judiciary interprets the laws but it is the legislative branch that passes laws. Congress (the legislative branch) should be petitioned to change the law. That's their job and, unlike judges, Congress is elected and can be lobbied. BIO and similar organisations should lobby Congress to make the Dyk solution a law. A law that the Supreme Court could then easily interpret as favourable to the most innovative of ideas and patents.

\section{Association for Molecular Pathology v. Myriad Genetics - Gene Patent, Profits and Pirates}

By 1990 linkage analysis had shown that something on the long arm of human chromosome 7 associated with a high propensity for breast cancer (BReast CAncer). Myriad Genetics was spun out of the University of Utah in 1994 and they published the sequence of BRCA (1) after filing a patent application [12]. The next year they discovered its doppelganger, BRCA2, and applied for a patent for it too. By 1996, Myriad was offering its diagnostic testing services for the BRCA genes.

A couple thousand human genes have been patented. In the process of cloning and sequencing them, each gene had been isolated and modified. These compositions of matter are not found in nature so they are not a product of nature -they were considered a product of man's modification of nature. This, it was argued (successfully for decades) made them eligible for a patent. Many biotech companies had been established based solely on a gene patent.

However, over the decades, that line of argument lost its strength and the public's opinions of gene patenting changed. Kits now made the isolation and modification of a gene so easy that a child can do it. Opponents of the technology found that steering their message towards a personal perspective won them many supporters. ("They're patenting your genes -the genes your parents gave you and hope to give to your children!") The argument that the temporary monopoly provided by a gene patent was required to offset the costs of its discovery, was (is) now perceived by many people as a weak excuse to for ... greed.

Myriad's business model required that they vigorously defend their gene patents to maintain exclusivity and thus control the price of their diagnostic services. Clinical pathologists received "cease and desist letters" from Myriad warning them to stop testing for the BRCA genes -both in their research and in their service (supporting the hospitals often associated with their universities). Myriads positioned threatened the sacrosanct principles of researcher freedom, to study nature and conduct experiments. Research into cures for breast cancer would be harmed -perhaps grind to a halt. Another concern was that Myriad's exclusivity made it impossible to get a second opinion. Pathologists asked, "How do I know the result of a BRCA test is right if I cannot get independent confirmation?" Myriad's position was bad medicine. This had to go to court and the Association for Molecular Pathology (AMP) lead the plaintiffs.

AMP asked the Southern District Court of New York to rule invalid 14 specific claims on

1. isolated genes,

2. diagnostic methods, and

3. methods to identify drug candidates,

in seven of Myriad's twenty-three BRCA patents. AMP argued these claims are not patentable subject matter under $\$ 101$ of Title 35 of the United States Code because

1. these genes are products of nature, so unpatentable.

2. the diagnostic method claims are thought processes that do not yield any real world transformations, so fail the "machine or transformation test."

3. the drug screening claims were a bold attempt to own the process of conducting research.

The judge for the District Court, Judge Robert W. Sweet [13], agreed with AMP and declared the 14 claims invalid. 
Judge Sweet stated,

1. 'DNA's existence in an 'isolated' form alters neither this fundamental quality of DNA as it exists in neither the body nor the information it encodes. Therefore, the patentsat issue directed to 'isolated DNA' containing sequences found in nature are unsustainable as a matter of law and are deemed unpatentable under 35 U.S.C. \$101."

2. The comparisons of DNA sequences are abstract mental processes (under the in re Bilski decision), so unpatentable.

3. The drug screening claims were unpatentable because they cover a "basic scientific principle".

A couple weeks later Myriad filed its notice to appeal.

The decision by the United States Court of Appeals for the Federal

Circuit might be summarised as " 2 to 1 in Myriad's favour". This Court:

1. Overturned the district court's decision on an isolated DNA sequence, saying these genes are patentable (as had been the case for years).

2. Affirmed the district court's decision that Myriad's claims for comparing DNA sequences are patent-ineligible (because they are a thought process).

3. Overturned the district court's decision that methods for screening cancer therapeutics is patent-ineligible, making them eligible

AMP petitioned the Supreme Court to review the case. The Court vacated the Federal Circuit decision and remanded the case back to them. The Supreme Court expected the Federal Circuit to take into account its recent decision in Mayo Collaborative Services v. Prometheus Laboratories, Inc. However, these "do over" concluded the same way, "2 to 1 in Myriad's favour". The new opinion was very similar to its first, other than adding the Mayo $v$ Prometheus decision to affirmed the district court's ruling that Myriad's claims for comparing DNA sequences are patent-ineligible (because they are a thought process).

The majority opinion said the Mayo precedent was not relevant regarding the patentability of genes, because it did not deal with the patent eligibility of gene patents. Writing for the majority, Judge Lourie stated: "The remand of this case for reconsideration in light of Mayo might suggest, as Plaintiffs and certain amici state, that the composition claims are mere reflections of a law of nature. Respectfully, they are not, any more than any product of man reflects and is consistent with a law of nature."

On this point Judge William Bryson dissented writing,

"In Mayo, which involved method claims...the [Supreme] Court found that the method was not directed to patent-eligible subject matter because it contributed nothing "inventive" to the law of nature that lay at the heart of the claimed invention...In concluding that the claims did not add "enough" to the natural laws, the Court was particularly persuaded by the fact that "the steps of the claimed processes...involve well-understood, routine, conventional activity previously engaged in by researchers in the field.

Just as a patent involving a law of nature must have an "inventive concept" that does "significantly more than simply describe...natural relations,"... a patent involving a product of nature should have an inventive concept that involves more than merely incidental changes to the naturally occurring product. In cases such as this one, in which the applicant claims a composition of matter that is nearly identical to a product of nature, it is appropriate to ask whether the applicant has done "enough" to distinguish his alleged invention from the similar product of nature. Has the applicant made an "inventive" contribution to the product of nature? Does the claimed composition involve more than "well-understood, routine, conventional" elements? Here, the answer to those questions is no."

The American Civil Liberties Union and the Public Patent Foundation filed another petition with the Supreme Court and the Court agreed to hear the plaintiffs' appeal of the Federal Circuit's ruling.

The Supreme Court delivered its opinion [14] "A naturally occurring DNA segment is a product of nature and not patent eligible merely because it has been isolated, but cDNA is patent eligible because it is not naturally occurring."

Perhaps with Ariosa v. Sequenom in mind, Judge Bryson, speaking for the majority wrote, "... [a]s the first party with knowledge of the sequences, Myriad was in an excellent position to claim applications of that knowledge. Many of its unchallenged claims are limited to such applications."

The majority would have been unanimous and complete except for Justice Antonin Scalia, who felt compelled to write, "I join the judgment of the Court, and all of its opinion except Part I-A and some portions of the rest of the opinion going into fine details of molecular biology. I am unable to affirm those details on my own knowledge or even my own belief. It suffices for me to affirm, having studied the opinions below and the expert briefs presented here, that the portion of DNA isolated from its natural state sought to be patented is identical to that portion of the DNA in its natural state; and that complementary DNA (cDNA) is a synthetic creation not normally present in nature."

\section{Conclusions}

As molecular diagnostics help to better identify tumour types [15], thus the gene sequences and their expression patterns that characterise the disease become of considerable economic value to their discovers through protection as intellectual property rights. However, as our case studies demonstrate, upholding of IPR is often surprisingly arbitrary and unpredictable, creating a situation where the cost of supporting the prosecution of IPR could be unrewarding. Revenues that flow from the licencing of well-protected IPR are key to the profitability that rewards shareholders and funds investment in further R\&D activities. In terms of personalised medicine, the returns from $\mathrm{CDx}$ and $\mathrm{cDx}$ with proven clinical utility in guiding the right medicine to the right patient are crucially dependent on good protection of intellectual property rights. The loss of such protection and the consequent loss of economic returns may then lead to loss in patient benefits as tests are lost from the market; it thus seems key to the ongoing growth of personalised medicines that IPR is managed as part of key corporate strategies.

\section{References}

1. Blair ED (2010) Molecular diagnostics and personalized medicine: value assessed opportunities for multiple stakeholders". Personalized Medicine 7 143-161.

2. Blair ED, Ther MD (2008) Assessing the Value-Adding Impact of DiagnosticType Tests on Drug Development and Marketing. Molecular Diagnosis and Therapy 12: 331-339.

3. GenomeWeb, https://www.genomeweb.com/molecular-diagnostics/cms-restoresreimbursement-rate-oncotype-dx-breast-cancer-test, accessed 26th August 2016. 
4. Chakrabarty VD (1980) Certiorari to the United states Court of appeals for the federal Circuit. Mayo collaborative Services, dba mayo medical laboratories, et al. v. Prometheus laboratories, Inc. Supreme court of the United States, 447 U.S. 303.

5. Seidman GE, Théorêt $Y$ (2002) Method of Treating Ibd/Crohn's Disease And Related Conditions Wherein Drug Metabolite Levels in Host Blood Cells Determine Subsequent Dosage Grant Application number US 09/288,344.

6. Seidman EG, St-Luc S, Methods Of Optimizing Drug Therapeutic Efficacy For Treatment Of Immune-Mediated Gastrointestinal Disorders 10/034,456, US Patent.

7. Bilski K (2010), Under secretary of commerce for intellectual property and director, patent and trademark office" no. 08-964. United States Supreme Court, USA.

8. Stephen MS, Donald BV (2011) Mayo collaborative services, dba mayo medical laboratories, et al. V. Prometheus laboratories, inc No. 10-1150. Prometheus Laboratories, Inc, USA

9. Yuk-Ming DL, Wainscoat JS (2001) Non-Invasive Prenatal Diagnosis 09/380,696. CA2282793A1, USA.

10. Hockaday $T$ (2014) Sequenom purchases non-invasive prenatal testing intellectual property from Oxford University, UK.
11. Holman MC, Williams H (2015) Ariosa Diagnostics, Inc., and Natera, Inc. Plaintiffs-Appellees, and DNA Diagnostics Center, Inc., Counterclaim Defendant-Appellee, v. Sequenom, Inc., and Sequenom Center for Molecular Medicine, LLC, Defendants-Appellants, and ISIS Innovation Limited, Defendant (United States Court of Appeals for the Federal Circuit). United States Court of Appeals for the Federal Circuit 34: 171-175

12. Holman MC, Williams $H$ (2014) Ariosa diagnostics, inc., natera, inc., plaintiffsappellees dna diagnostics center, inc, counterclaim defendant-appellee $v$. Sequenom, inc., sequenom center for molecular medicine, Ilc, DefendantsAppellants ISIS INNOVATION LIMITED, Defendant, United States District Court for the Northern District of California 1139-1144.

13. Roberts C (2013) Association for Molecular Pathology v. U.S. Patent and Trademark Office, No. 09-cv-4515, 94 USPQ2d 1683 (S.D.N.Y. March 29, 2010). District Court Decision.

14. Goddard J, Glantz Z (2013) Association for molecular pathology et al. V. Myriad genetics, inc., et al. No. 12-398. Supreme Court Of The United States.

15. Araya CL, Cenik C, Reuter JA, Kiss G, Pande VS, et al. (2016) Identification of significantly mutated regions across cancer types highlights a rich landscape of functional molecular alterations. 48: 117-125. 